$\overline{\text { 論 文 }}$

\title{
けい光放電管の輝きにおよぼすけい光体膜の影響
}

正会員 坊 博 * 専門会員 竹 山 説 三*

\section{The Effects of Phosphor Coating on the \\ Brightness of the Fluorescent Lamp}

By Hiroshi Bō (Member) and Setsuzo Takeyama (Fellow Member)

(Faculty of Engineering, Osaka University)

\begin{abstract}
The intensity of the generated light from the phosphor coating excited by the ultraviolet rays, such as in a fluorescent lamp has been calculated for the coating thickness using the Kubelka's formula, in which the scattering of the light in the medium is treated. The multiple reflections of the light between the phosphor particles and between the phosphor coating and the glass of the bulb wall have been considered in this report. Also the light from the fluorescent lamp, in which the inner surface of the cylindrical glass tube is coated with phosphor has been obtained by considering the effect of the interreflection in the finite cylindrical tube and the reflectance and the tranamittance of the glass tube.
\end{abstract}

Good agreement has been obtained between the results of calculations and measurements, except for the case of the thin phosphor coating or non-homogeneous coating.

\section{1. 緒 言}

沙い光灯の発光特性に重要な影響をなるるよ゙すー..つの要 素としてけい光物筫が考光られる。けい光物質そのもの の製造に関してはその関倸方面て研究されている。しか しそのい光物質の塗布状態々その発光強度（輝き）と に関しては，従来加ら実験的に検討されているが，1）2》 理諭的には内部に把ける散乱を無視した場合につきG1ocker ") 等が計算しているにすぎない，実験的には Th-

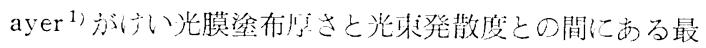
適条件考見出し，その条件とけい光凌の光学的性質，例 えばけい光膜の透過率とを関係づけている。今回これら 実験結果を理諭的に検討するため,けい光物質膜内に把 ける散乱在考慮し，かつけい光放電管の管壁ガラスの影 響や，放電管内に括ける相互反射等を考虑に入れて理論 的に取扱い，けい光膜の塗布状態と光束発散度との関係 在導びいた。 その結果, 従来, とかく阽万そかにされが ちなけい光膜の紫外線に対する性質, すなわちその吸収 係数, 反射係数等が可視光線に対するものと同等に重要 な役割ななしていることが判明した。

* 大阪大学工学部

\section{2. けい光体粉末膜の光学的性質}

けい光体粉末を固めた試料 (けい光膜) の光学的性質 は, 従来加らく取扱われている均質な媒質の光学的性 質とはその趣を異にする。すなわちその試料内では光の 吸収の外に強い散乱が行われる。このような問題を巨視 的に取报ったのに P.Kubelka の理論4)がある.とてで はその理論を用い, 沙い光膜の光学的性質を謂べる.

試料に一方向から光が入射する場合, 境界面に鉛直で 媒質の内部に向う力向を $x$ 軸にとり，その $x$ 軸に鉛直な 単位而皘を正方向 (入射方向) に沿って進光光の強さを $i$, 負の方向に進克光の強さを $j$ とすれば, 次の微分方 程式が得られる。

$$
\begin{aligned}
& d i / d x=-(\alpha+\beta) i+\beta j \\
& d i / d x=(\alpha+\beta) j-\beta i
\end{aligned}
$$

ここで， $\alpha$ 扮よで $\beta$ は吸収打よじ散乱による光の揁失 を表方す伱数である.

上式を簡単にすれば

$$
\begin{aligned}
& d^{2} i / d x^{2}=\beta^{2} b^{2} i \\
& j=\frac{1}{\beta} d i / d x+(1+q) i=-\frac{1}{\beta} d i / d x+a i \\
& d^{2} j / d x^{2}=\beta^{2} b^{2} j
\end{aligned}
$$


ここで

$$
b^{2}=\left\{(1+\alpha / \beta)^{2}-1\right\}=\left(a^{2}-1\right)
$$

ただし $a=1+\alpha / \beta=1+q$

$$
\alpha / \beta=q
$$

したがってこの微 分方程式党適当な境 界条件で解沙ばよい ことになる、今第 1 図のごとくけい光膜 の原さを $d$ とし,$x$

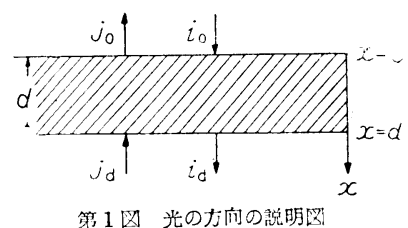

方向を罒のごとくとれば

$$
\begin{array}{ll}
x=0 & i=i_{0} \\
x=d & j=j_{0} \\
& i=i_{d} \\
j & =j_{l}
\end{array}
$$

と轮くことができる。そうすると（2.3）(2.4）の解は

$$
\left.\begin{array}{l}
i=c_{1} e^{-\gamma^{(x-d)}}+c_{2} e^{\gamma^{(x-d)}} \\
j=(a-b) c_{1} e^{-\gamma^{(x-d)}}+(a+b) c_{2} e^{(x-d)}
\end{array}\right\}
$$

ただし

$$
\begin{aligned}
& c_{1}=\frac{i_{0}-i_{d} e^{-\gamma^{d}}}{e^{\gamma^{d}}-e^{-\gamma^{d}}} \quad c_{2}=\frac{i_{d} e^{\gamma^{d}}-i_{0}}{e^{\gamma^{d}}-e^{-\gamma \gamma^{d}}} \\
& \gamma=\beta b, \quad a=\frac{\alpha+\beta}{\beta}=\frac{\alpha}{\beta}+1, \quad b=\sqrt{a^{2}-1}
\end{aligned}
$$

実際は比較的容易に测定できる量

$$
\begin{aligned}
& R(d)=j_{0} / i_{0} \\
& T_{(d)}=i_{d} / i_{0}
\end{aligned}
$$

を定義し，これらをそれぞれけい光膜の反射信打よご透 過率と名づける.

厚さ $x$ の膜の反射率 $R(x)$ 叔よ已゙透過率 $T(x)$ は

$$
\begin{aligned}
& R_{(x)}=\frac{\sin h \gamma x}{a \sin h \gamma x+b \operatorname{csoh} \gamma x} \\
& T_{(x)}=\frac{b}{a \sin h \gamma x+b \cosh \gamma x}
\end{aligned}
$$

で表わされ， $x \rightarrow \infty$ のとさ $R_{(x)}$ 打よび $T_{(x)}$ を $R_{\infty}$, $T_{\infty}$ とすれば

$$
R_{\infty}=1 /(a+b), \quad T(\infty)=0
$$

となり, $a, b$ は

$$
\begin{aligned}
& a=1 / 2\left(1 / R_{\infty}+R_{\infty}\right) \\
& b=1 / 2\left(1 / R_{\infty}-R_{\infty}\right)
\end{aligned}
$$

で表わされる。また任意の厚さ $x$ に招ける $R$ と Tがわか れば

$$
\begin{aligned}
& R_{\infty}=4 R /\left\{3+R^{2}-T^{2} \pm \sqrt{\left(1+T^{2}-R^{2}\right)^{2}-4 T^{2}}\right\} \\
& e^{x}=4 T /\left\{1+T^{2}-R^{2} \pm \sqrt{\left(1+T^{2}-R^{2}\right)^{2}-4 T^{2}}\right\}
\end{aligned}
$$

により， $R_{\infty}, \gamma$ が求められる，したがって

$$
\begin{aligned}
& a=\frac{1}{2}\left\{\frac{1}{R_{\infty}}+R_{\infty}\right\}, \quad b=\frac{1}{2}\left\{\frac{1}{R_{\infty}}-R_{\infty}\right\} \\
& \beta=\frac{\gamma}{b}
\end{aligned}
$$

$$
\alpha=\beta(a-1)
$$

が求められ，各種の係数が決定できる。

また（2.8）打よび（2.9）と $R_{\infty}$ との関係は

$$
\begin{aligned}
& R_{(x)}=\frac{R_{\infty}\left\{e^{\gamma^{x}}-e^{-\gamma^{x}}\right\}}{e^{\gamma^{x}}-R_{\infty}^{2} e^{-\gamma^{x}}} \\
& \because(x)=\frac{1-R_{\infty}^{2}}{e^{\gamma^{x}}-R_{\infty}{ }^{2} e^{-\gamma^{x}}}
\end{aligned}
$$

で表わされる。委た， $x$ が非常に大きくなれば，(2.9） 式は

$$
T=b \cdot e^{-\gamma^{x}}
$$

上なるから, 厚い試料のTの曲線の傾斜加ら功決定で きる。

\section{3. 紫外線励起による発光強度}

けい光膜の外部紫外線励起による発光汇閶しては,

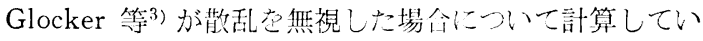
るが，ここでは散乱を考慮に入机た前述の反射率媇よご 透過淬堂用いて計算しょう。

今, けい光膜の厚さ学 $d$ とし，強さ $u_{0}$ なる紫外線为 これに投射された場会, 膜内の任意の位置 $x$ 亿北沙了紫 外線強度は前節と同様，散乱を考虑して求めねばならな いが，実験結果より散乱を無視して吸収のみを考えて取 扱えることが判明したので，吸収のみ考宑して求める と,

$$
u_{(x)}=u_{0} e^{-a^{\prime} x}
$$

ここに $\alpha^{\prime}$ は沙い光体の紫外線に対する财収倸数である, 励起紫外線とけい光体の発光強度との間には, 通常慨和 が㸾められていないから，愿さ $d x$ なる層に吸収される 紫外線 $\alpha^{\prime} u \cdot d x$ 亿卡

$$
d H_{0}=k_{0} \alpha^{\prime} u \cdot d x
$$

なる可視光線が発生するものとする。ただし， $k_{0}$ は紫外 線を可視光に変換する効率である.

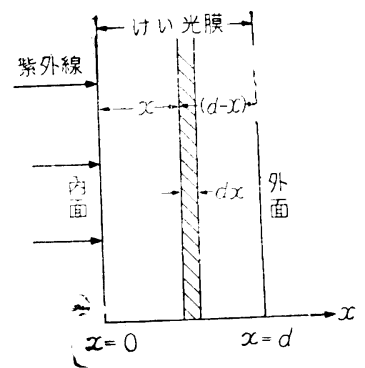

ナい光膜の発光は, 放電 管の外面とその内面とに分 けて考光られ襍なら收禺 え，次にその両者につき計 算する。

\section{(i) 内面の発光強度}

今，第 2 図のごとく $x=$ 0 の面に紫外線が入射する 第 2 因けい光膜と幽㯲との関係ものとすれば， $x$ なる位置 で $d x$ なる微少薄膜内で紫外線により励起される光

$$
d H_{0}=k_{0} \alpha^{\prime} u \cdot d x=k_{0} \alpha^{\prime} u_{0} e^{-\alpha^{\prime}} d x
$$

が, $d-x$ なる厚さのけい光膜を通過して $x=d$ 亿出てく る強度 $d H$ は，膜内に打ける相互反射を考虑に入れる と，付録 Iより，

$$
d H=\frac{1+R_{(x)}}{1-R_{(x)} \cdot R_{(d-x)}} \cdot T_{(d-x)} \cdot k u_{0} \alpha^{\prime} e^{-\alpha^{\prime x}} d x
$$




$$
=\alpha^{\prime} k u_{0} \cdot \frac{\left(1+R_{(x)}\right) \cdot T_{(d-x)}}{1+R_{(x)} \cdot R_{(d-x)}} \cdot e^{-\alpha^{\prime \prime}} d x \cdots
$$

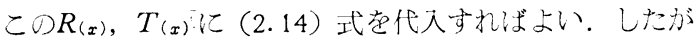
って, 厚さ $d$ なる膜全体より表面 $x=d$ に出てくる光の

強さは

$$
\begin{aligned}
& H_{02}=\int_{0}^{d} d H=\alpha^{\prime} k u_{0} \int_{0}^{d} \frac{\left(1+R_{(x)} \cdot T_{(d-x)}\right.}{1-R_{(x)} \cdot R_{(d-x)}} \cdot e^{-\alpha^{\prime} x} d x
\end{aligned}
$$

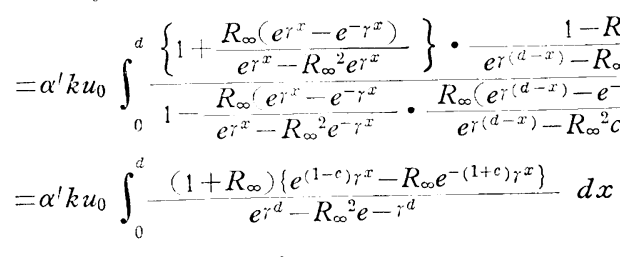

$$
\begin{aligned}
& =\frac{\alpha^{\prime} k u_{0}\left(1+R_{\infty}\right) \gamma^{d}}{e^{2} \gamma^{d}-K_{\infty}^{2}} \int_{0}^{d}\left\{e^{(1-c) \gamma^{d}}-R_{\infty} e^{-(1+c) \gamma^{-x}}\right\} d x \\
& =\alpha^{\prime} k u_{0} \cdot \frac{e^{\gamma^{d}}}{e^{2} \gamma^{d}-R_{\infty}^{2}}\left[\frac{e^{(1-c) \gamma^{2}}}{(1-c) \gamma}+\frac{R_{\infty}}{(1+c) \gamma}\right. \\
& \left.\times e^{-(1+c) r^{2}}\right]_{0}^{d} \\
& =\frac{\left(1+R_{\infty}\right) k u_{0}}{e^{2} \gamma^{d}-R_{\infty}^{2}} \cdot \frac{\alpha^{\prime} e^{-c} \gamma^{d}}{\left(1-c^{2}\right) \gamma} \\
& \times\left[(1+c) e^{2 \gamma^{d}}-\left\{(1+c)+(1-c) R_{\infty}\right\}^{(1+c) \gamma^{d}}\right. \\
& \left.+(1-c) R_{\infty}\right] \\
& =\frac{\left(1+R_{\infty}\right) k u_{0}}{e^{2} \gamma^{d}-R_{\infty}^{2}} \cdot \frac{c e^{-c} \gamma^{d}}{(1-c)} \\
& \times\left[(1+c) e^{2} \gamma^{d}-\left\{(1+c)+(1-c) R_{\infty}\right\} e^{(1+c) \gamma^{d}}\right. \\
& \left.+(1-c) R_{\infty}\right] \\
& \text { ただし } c=\alpha^{\prime} / \gamma \\
& \text { 今 } c \ll 1 \text { なるときは } \\
& H_{d}=c e^{-c_{\gamma}^{d}} \cdot \frac{\left(1+R_{\infty}\right) k u_{0}}{e^{\gamma^{d}}+R_{\infty}}\left(e^{\gamma^{d}}-1\right) \\
& c \doteqdot 10<き \\
& H_{d}=\frac{c e^{-c} \gamma^{d}}{\left(1-c^{2}\right)} \cdot \frac{\left(1+R_{\infty}\right) R_{\infty}}{e^{2 \gamma^{d}}-R_{\infty}^{2}} \cdot k u u_{0} \\
& H_{d}=\frac{k u_{0}\left(1+R_{\infty}\right)}{e^{2 \gamma^{d}}-R_{\infty}^{2}} \cdot e^{-c} \gamma^{d}\left\{R_{\infty}+\left(1-R_{\infty}\right) e^{c} \gamma^{d}-e^{2 \gamma^{d}}\right\} \\
& d \mathrm{~m}=\frac{1}{\gamma} \log \frac{1}{2}\left\{\left(1-R_{\infty}\right)+\frac{1}{c}\left(1+R_{\infty}\right)\right. \\
& \pm \sqrt{\left.\left\{\left(1-R_{\infty}\right)+\frac{1}{c}\left(+R_{\infty}^{2}\right)\right\}^{2}-4-\frac{R_{\infty}}{c \gamma}\right\}} \\
& \doteqdot \frac{1}{\gamma} \log \frac{1}{2}\left\{\left(1-R_{\infty}\right)+\frac{1+R_{\infty}}{c}\right. \\
& \left. \pm \sqrt{\left(\frac{1+R_{\infty}}{c}\right)^{2}-4 \frac{\mathrm{R}_{\infty}}{c \gamma}}\right\}
\end{aligned}
$$

でこのとさの $H$ の最大值 $H_{d m}$ は

$$
\begin{aligned}
& H_{d m} \doteqdot c k u_{0}\left(1+\mathrm{R}_{\infty}\right)\left(-\frac{1+R_{\infty}}{c}\right. \\
& \pm \sqrt{\left.\frac{\left(1+\mathrm{R}_{\infty}\right)^{2}}{c^{2}}-\frac{4+\mathrm{R}_{\infty}}{c \gamma}\right)^{-c}}
\end{aligned}
$$

$$
\begin{aligned}
& \doteqdot c k u_{0}\left(1 \gamma+\mathrm{R}_{\infty}\right)\left(\frac{1+\mathrm{R}_{\infty}}{c}\right. \\
& \left. \pm \sqrt{\left(-\frac{1+\mathrm{R}_{\infty}}{c}\right)^{2}-\frac{4 \mathrm{R}_{\infty}}{c \gamma}}\right)^{-c}
\end{aligned}
$$

またcち1のとき

$$
\begin{aligned}
& d \mathrm{~m}=\frac{1}{2 \gamma}\left\{\log \mathrm{R}_{\infty} c \gamma-\log (c \gamma+2 \gamma)\right\} \\
& \cdot e^{-\alpha^{\prime} x}-d x \mid=\frac{1}{2 \gamma} \cdot \log \frac{\mathrm{R}_{\infty} c}{c+2}
\end{aligned}
$$

$$
H_{\mathrm{dm}}=k u_{0}-\frac{\left(\mathrm{R}_{\infty}^{2}+\mathrm{R}_{\infty}\right) \cdot c^{2}}{2\left(1-c^{2}\right)}\left(\frac{c+2}{\mathrm{R}_{\infty}^{2} c}\right)^{\left(\frac{c}{2}+1\right)}
$$

となる.（3.2）式で表わされるようにけい光体の紫外線

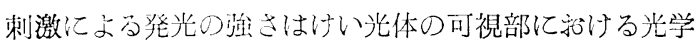
的性質のみなら紫外線に対守る吸收係数 $\alpha^{\prime}$ とと との 比, すなわちcにより左右せられ，cの值いかんにより 最高光度出出す最適应子多異ってくることがわかる。な 打一般の場合の最適鼠さ $d \mathrm{~m}$ 扔よびそのとさの強度 $\mathrm{Hm}$ は複雑でここでは求的てない。

\section{(ii) 内面の発光強度}

$x=0$ 与な⿰七内面 0 発光強度 $H_{01}$ 前述と同様に求

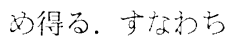

$$
\begin{aligned}
H_{u 1} & =\alpha^{\prime} k u_{0} \int_{0}^{d} \frac{\left(1+R_{(d-x)}\right) \cdot T(x)}{1-R_{(x)} \cdot R_{(d-x)}} \cdot e^{-a^{\prime x}} d x \\
& =\frac{\alpha^{\prime} k u_{0}}{\gamma} \cdot \frac{1+R_{\infty}}{\left(e^{2 \gamma^{d}}-R_{\infty}^{2}\right.} \\
\times & \left\{\frac{\left.e^{2 \gamma^{d}}-e^{(1-c) \gamma^{d}}-\frac{R_{\infty}\left(e^{\left(1-c \gamma^{d}\right.}-1\right)}{1-c}\right\}}{1+c}\right\} \\
& =\frac{\alpha^{\prime} k u_{0}}{\gamma} \cdot \frac{\left(1+R_{\infty}\right)}{e^{2 \gamma^{d}}-R_{\infty}^{2}} \\
\times & \left\{\frac{e^{2 \gamma^{d}}}{1+c}-\left(\frac{1}{1+c}+\frac{R_{\infty}}{1-c}\right) e^{(1-c) \gamma^{d}}+\frac{R_{\infty}}{1-c}\right\} \\
& =\frac{c k u_{0}}{\left(1-c^{2}\right)} \cdot \frac{1+R_{\infty}}{e^{2 \gamma^{d}}-R_{\infty}^{2}} \\
& \times\left[(1-c) e^{2 \gamma^{d}}-\left\{(1-c)+(1+c) R_{\infty}\right\} e^{(1-c) \gamma^{d}}\right. \\
& \left.+(1+c) R_{\infty}\right]
\end{aligned}
$$

となる.（3.9）式で表わされる内部の発光強度はけい光 灯のごとき円筒の内面の場合には, その内面の光束発散 度は円筒内面に扔ける相互反射により堌加することが考 えられる. またけい光灯の場合はガラス円筒に塗布され ているため, このガラスの反射率扔よび透過率も影響し てくるため次にその問題在取扱う.

\section{4. 円筒内面における相互反射による 影響について}

円筒に抬ける相互 反射走取扱うため, 第 3 図のごとき直径 $D$, 長さ $l$ なる円筒 の内面にけい光膜の

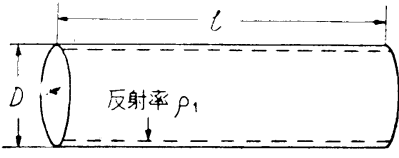

第3困 内にけい光膜を塗布した円筒と その寸法 
等価反射率 $\rho_{1}$ 老つものが塗布されているものとすれ ば，円筒の相互反射の式より5) 筒の端より $x$ なる点の光 束発散度 $H_{01(x)}$ は初めの相互反射走考えない場合の光 束発散度を $H_{01}$ とすれば

$$
\begin{aligned}
& \frac{H_{1}}{H_{01}}=-\frac{1}{1-\rho}+B_{1} \cosh \left(\alpha \cdot \frac{x}{l}\right)+c_{1} \sinh \\
& \left(\alpha \cdot \frac{x}{l}\right)
\end{aligned}
$$

で与えられる。ここに

$$
\begin{aligned}
B_{1} & =-\frac{\rho_{1} E}{1-\rho_{1}}\left[\left(1-\rho_{2}\right)\left(1-\rho_{3}\right) \sinh \alpha\right. \\
& +\sqrt{ } \frac{1-\rho_{1}}{1-} \cdot\left(1-\rho_{2}\right)\left(1+\rho_{3}\right) \cosh \alpha \\
& +\sqrt{ } \frac{1-\rho_{1}}{\left.\left.1-\rho_{2}\right)\left(1-\rho_{3}\right)\right]} \\
C_{1} & =\frac{\rho_{1}\left(1-\rho_{2}\right) E}{1-\rho_{1}}\left[\left(1-\rho_{3}\right) \cosh \alpha\right. \\
& +\sqrt{1-\rho_{1}}\left(1+\rho_{3}\right) \sinh \alpha-\left(1-\rho_{3}\right] \\
E & =\left\{\left[2\left(1+\rho_{2} \rho_{3}-\rho_{1}\left(1+\rho_{2}\right)\right] \sinh \alpha+2\right.\right. \\
& \sqrt{ } \frac{1-\rho_{1}}{\left.1-\rho_{2} \rho_{3} \cosh \alpha\right\}^{-1}}
\end{aligned}
$$

ただし円筒の両端面の反射率を $\rho_{2}, \rho_{3}$ とし，

$$
\alpha=2 k_{r} \sqrt{1-\rho_{1}} . \quad k_{r}=\frac{l}{D}=\frac{\text { 長さ }}{\text { 直径 }}
$$

今簡単のために円筒の両端面の反射率 $\rho_{2} . \quad \rho_{3}$ を零とし

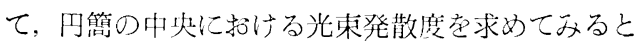

$$
\frac{H_{1 M}}{H_{01}}=\frac{1}{1-\rho_{1}}+B_{1}, \cosh \frac{\alpha}{2}+c_{1} \sinh \frac{\alpha}{2}
$$

ここで

$$
\begin{aligned}
B_{1} & =-\frac{\rho_{1} E}{1-\rho_{1}}\left[\sinh \alpha+\sqrt{1-\rho_{1}} \cosh \alpha\right. \\
& \left.+\sqrt{1-\rho_{1}}\right] \\
C_{1} & =\frac{\rho_{1} E}{1-\rho_{1}}\left[\cosh \alpha+\sqrt{1-\rho_{1}} \sinh \alpha-1\right] \\
E & =\frac{1}{\left(2-\rho_{1}\right) \sinh \alpha+2 \sqrt{1-\rho_{1}} \cosh \alpha}
\end{aligned}
$$

となる。したがっ $k_{r} 》 10$ 亿対して

となる。

$$
\frac{H_{1 M}}{H_{01}}=\frac{1}{1-\rho_{1}}
$$

第 4 図は $\rho_{1}=0.75,0.6,0.55$ にいて種々の $k_{r}$ に対 し中央の光束 発散度莡求め たもので, 図 より $k_{r}$ が大体 7 以上になれ ば飽和してそ れ以上は-・定 值に落ち着く ととがわか る, このこと はThayer ${ }^{1)}$ 屯

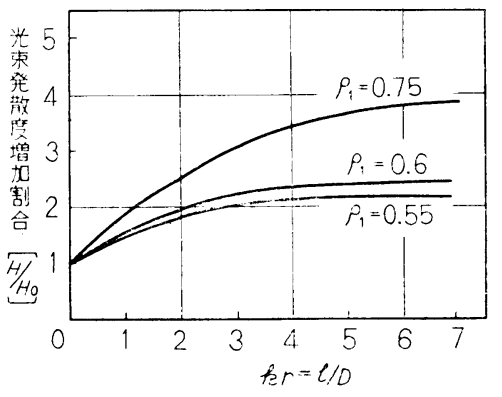

第4四 相互区射による内面占央部のかがやき增 加割合
実験的に求めて打り，次に第 5 図にその飽和值と各 $k_{r}$ の
ときの值との比で示した曲線を汃いてある。な打第 5 図 の点線は Thayer の夹験結果走示したものて， $\rho_{1}=0.55$ の朝線とよく一致している。したがってThayer の夷験

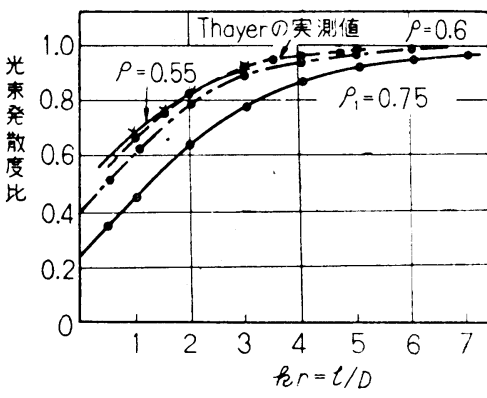

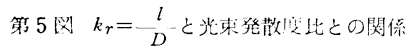

に使用した列 い光体の等価 反射率は 0.55 亡考光られ る。これは一 般の最適厚さ に対与万反射 率より少し小 さい值に出て いるが，これ はその実験が

けい光体を塗布したガラス円简の内部に紫外線ランプを 挿入して行われているため，その紫外線ランプによる光 の吸収のためけい光膜の等価反射率が小さく出たものと 考えられる。また（4.1）式で与えられる円筒に沿って の光束発散度分布は円简内部の初期の光束発散度が-様 で，一定の場合であるが，夹際の場合は放電状態による 影響で一様でない，したがって端部の輝き分布は（4.1） 式とは異ってくるので，この点については別稿に述心 る.

\section{5. 管壁ガラスの透過率および反射率の 光束発散度へおよぼす影響}

一般にけい光放電管に扔いては，以い光膜はガラス円 筒の内面に叙布されている。したがってけい光体より発 生した光は管照ガラスにより一部反射されけい光膜にも どり，それがまたけい光体內で反射を綝り返して出てく る。亦なわちけい光膜とガラス面との間で相互反射を行 なってガラス面外へ光は山てくるのであるから，これら の問题は相互反射の問題起解くことに帰着する。第 6 図 のごとく，平南ガラスにけ い光膜が塗布されている場 合老考える。命ガラスの反 射率 $\rho_{g}$, 透调率 $\tau_{g}$ とし, けい光膜のさを $d$ とし各 境界を第 6 図のごとくI， II，III，IVと名づて相互 反射考考虑与れば，付録 II より

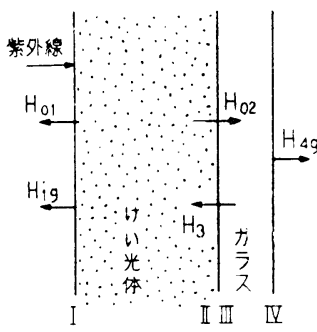

第 6 四ガラ又壁声もつけい光 体膜にょける光のた问の説明汹

内面の光束発散度 $H_{1 g}$ は

$$
H_{1 g}=H_{01}+\frac{\rho_{g} \cdot T_{(d)}}{1-\rho_{g} \cdot R_{(d)}} \cdot H_{02}
$$

また，ガラスを透過して出てくるものに対しては

$$
H_{4 g}=\tau_{g} H_{2}=\tau_{g}\left(1+\frac{\rho_{g} \cdot R_{(d)}}{1-\rho_{g} \cdot R_{(d)}}\right) H_{o 2}
$$




$$
=\frac{\tau_{g}}{1-\rho_{g} \cdot R_{(d)}} \cdot H_{02}=\tau_{g e} \cdot H_{02}
$$

となる，ここでR(d)，T(d) はそれぞれ厚さ $d$ なるけい光 膜の反射率打よ已゙透過乷在表わず。すなわち（5.1）式 よりガラス盟の反射の影響で初めの $H_{01} よ り\left(\rho_{g} \cdot(d)\right) /$ (1- $\left.\rho_{g} \cdot R_{(d)}\right) \cdot H_{02}$ の量だけ嬶加するととになり， ま たガラス在透過して出てくる光は初めの $H_{02}$ に等価透過 率 $\tau_{g e}$ 老乗じたものになる。乙の等洒透過率は相互反射 によるため，其の透過率 $\tau_{g} 01 /\left(1-\rho_{g} \cdot R_{(d)}\right)$ 倍になる ことが判明した。

\section{6. 円筒内の相互反射を考虑した場合のけい 光放電管内面および外面の光束発散度}

円筒内面の相互反射孛考虑しないでガラス壁の影響の みを考光た場合は（5.1）打よび（5.2）式より

内面 : $H_{1 g}=H_{01}+\frac{\rho_{g} \cdot T(d)}{1-\rho_{g} \cdot R_{(d)}} \cdot H_{02}$

外面: $H_{4 q}=\frac{\tau_{g}}{1-\rho_{g} \cdot R_{(d)}} \cdot H_{02}$

ここで

$$
H_{01}=\frac{c\left(1+R_{\infty}\right) k u_{0}}{\left(1-c^{2}\right) \cdot\left(e^{2 \gamma^{d}}-R_{\infty}^{2}\right)}
$$

$\times\left[(1-c) e^{2 \gamma^{d}}-\left\{(1-c)+(1+c) R_{\infty}\right\} e^{(1-c) \gamma^{d}}+(1+c) R_{\infty}\right]$

$$
H_{02}=\frac{c\left(1+R_{\infty}\right) k u_{0} \cdot e^{-c \gamma^{d}}}{\left(e^{2 \gamma d}-R_{\infty}^{2}\right)\left(1-c^{2}\right)}
$$

$\times\left[(1+c) e^{2 \gamma^{d}}-\left\{(1+c)+(1-c) R_{\infty}\right\} e^{(1+c) r^{d}}+(1-c) R_{\infty}\right]$

で表わされる。したがってこれに管内の相互反射による もの在重胃すればよいことになる。その場合けい光膜の 内面の反射率はけい光体だけの反射率だけではなく，ガ ラス壁の反射率と組合せた等価反射率を考元て計算せね ばならない，第6図のごとき場合のけい光体側より見た 反射率は Channon ${ }^{6)}$ 等により求められているごとく

$$
\rho_{p o}=R_{(d)}+\frac{T_{(d)}^{2} \cdot \rho_{g}}{1-R_{(d)} \rho_{g}}
$$

となることがわかる。この值を（4.1）（4.4）の式に括 ける $\rho_{1}$ として用うればよい.今非常に長い门筒, すな わち $\boldsymbol{k}_{y} 》 10$ とすれば，中心に打ける光束発散度は相互反 射の結果, 初めの1/(1- $\left.\rho_{p g}\right)$ 倍となるが, その面に入射 する光束密度.すなわち照度は $\frac{1}{\rho_{p g}}\left(\frac{1}{1-\rho_{p g}}-1\right) H_{1 g}$ となる.この光束がけい光体抢よびガラス面を透過して 出てくるから, 結局ガラス面外へ出る光束密度は

$$
H^{\prime}=\tau_{p g} \cdot \frac{1}{\rho_{p g}}\left(\frac{1}{1-\tau_{p g}}-1\right) H_{1 g}=\frac{\tau_{p g}}{1-\rho_{p g}} \cdot H_{1 g}
$$

となる. ここで $\tau_{p g}$ はけい光膜とガラスとを複合した層 の透過率で” $\rho_{p g}$ 亡同様にして $\left.{ }^{6}\right)$ 求められ

$$
\tau_{p g}=T_{(d)} \cdot \tau_{g} /\left(1-R_{(d)} \cdot \rho_{g}\right)
$$

で表わされる。

したがって管外への光束発散度は

$$
\begin{aligned}
H= & H_{4 g}+H^{\prime}=H_{4 g}+\frac{\tau_{p g}}{1-\rho_{p g}} \cdot H_{1 g} \\
= & \frac{\tau_{q} \cdot H_{02}}{1-\rho_{g} \cdot R_{(d)}}+\frac{\tau_{p g}}{1-\rho_{p g}}\left(H_{01}+\frac{\rho_{g} \cdot T_{(d)}}{1-\rho_{g} \cdot R_{(d)}}\right. \\
& \left.\cdot H_{02}\right) \\
= & \frac{\tau_{p g}}{1-\rho_{p g}} H_{01}+\frac{\tau_{g}+\rho_{g} \cdot T_{(d)}}{1-\rho_{g} \cdot R_{(d)}} \cdot H_{02} \quad(6.6)
\end{aligned}
$$

（6.7）式は円筒内に执ける相互反射考虑したものであ るが，乙れは円筒の長さと直径の比 $k_{r}$ が 10 以上の場合 の円筒の中心に拝ける值である。もし筒に沿っての分布 とか，任意の $k_{r}$ に対するものが必要な場合は（6.6）式 のH值として

$$
H^{\prime}=\frac{\tau_{p g}}{\rho_{p g}}\left(\frac{H_{1}}{H_{01}}-1\right) \cdot H_{1 g}
$$

ここで $H_{1} / H_{01}$ は (4.1) 式のものを使用すればよい.

また (6.6) 式は次のように書ける.

$$
H=\tau_{e 1} \cdot \mathrm{H}_{01}+\tau_{e 2} \cdot \mathrm{H}_{02}
$$

ここで $\tau_{e 1}=\tau_{p g} /\left(1-\rho_{p g}\right), \quad \tau_{e 2}=\left(\tau_{g}+\rho_{G} \cdot T_{d}\right) /\left(1-\rho_{g}\right.$ $\left.R_{(d)}\right)$ 之打く，第 7 図にとの $\tau_{e 1}, \tau_{e 2}$ と塗布量との関係 の夷例を示す。ただしガラスの反射率扮よび透過率を 0.08, 0.9 として計算せるもので，図よりわかるごとく $\tau_{e 2}$ の方は狳布量によりあまり変らず, 大体 0.97 の附近 であるが， $\tau_{e 1}$ の方は塗布量の増加とともに減少するこ とがわかる。したがって（6.8)式より容易に非常に長い 放電管 $\left(\frac{l}{D}>7\right)$ の中央外面の全光束発散度が計算でき るととが判明した．との(6.8) 式に捣いてガラスの影響 整無視するとHは

$$
H=\frac{T_{(d)}}{1-R_{(d)}} \cdot H_{01}+H_{02} \doteqdot H_{01}+H_{02}
$$

に近似できる。

\section{7. 実例の計算および検討}

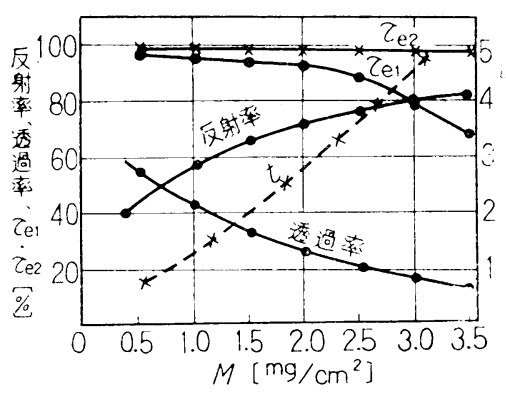

冷白色用け い光体につい てのその膜の 塗布厚さと反 射率打よび透 過染の...例党 第 7 図に示す との図に把い て厚さは単位 第 7 図 颈布显と透過率, 反率および $\tau_{e 1}, \tau_{12}, \mathrm{t}$ との関係 面積当りの重 量 $M$ で示し, 测定は G. E. Recording Spectrophotmeter にて積分球を使用して行なった. 図より， $R_{\infty}=0.86$ 之 して $a, b$ を求めると $a=1.011, b=0.15$ となる. また (2.8) 式より 


$$
\gamma x=\operatorname{coth}^{-1} \frac{1-a R_{(x)}}{b R_{(x)}}
$$

となり, $\gamma=b \beta$ なる故

$$
\therefore \beta x=\frac{1}{b} \operatorname{coth}^{-1} \frac{1-a R_{(x)}}{b R_{(x)}}=t
$$

$t$ 扎よび $b t=m$ 在新しい等西厚さとして導入することに なる.この $t$ と単位面積当りの重量 $M$ との関係求和 ば第 7 図の曲線のごとくなる。市た, 他の白色打光体 についてボールミルによる粉砕時間变えて, 同様な测 定在行なったものに対する $t$ と $M$ との関係を第 8 図に示

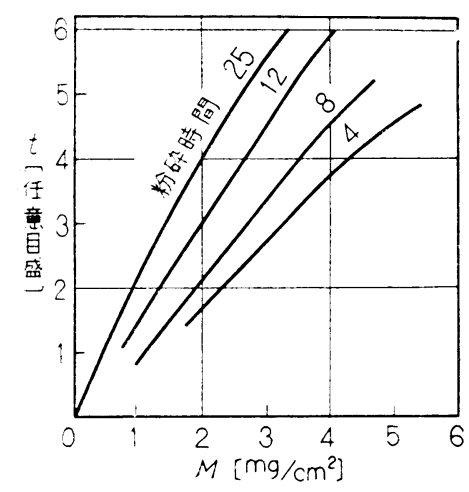

第 8 图 粉砕時間飞よ的の变化
す。第 8 図上り粉 砕時間により同じ 単位面積当りの重 量 $M$ に打いても $t=\beta x$ は界ること が判明する。すな わち粉确時間が長 いほど同じMに対 しては大となって いる.このことは 粉砕時間が長くな ればけい光体の粒

度が小さくなり散乱倸数の $\beta$ が大乞なるためと考えられ る. 以上光学的な反射率扔よび透過率と厚さとの関係デ 一ターより散乱を考虑した場合の理論式の諸常数が決定 できる.よって次にけい光灯の外部へ発する光束発散度 を(6.6) 式で求めればよいのであるが，その前に (3.2) （3.9）式より $H_{02}, H_{01}$ を求めねばならない，第 9 図は 第7图の冷白色けい光体について算した $H_{01}$ 抢よび $H_{02}$ の值と,

$b t=m$ との

関係走す。 ここで紫外 線の吸収 係数 $\alpha^{\prime}$ と $\gamma=b \beta$ との 比 $c$ が問題 になるが, $\beta$ が非常に 小さいと

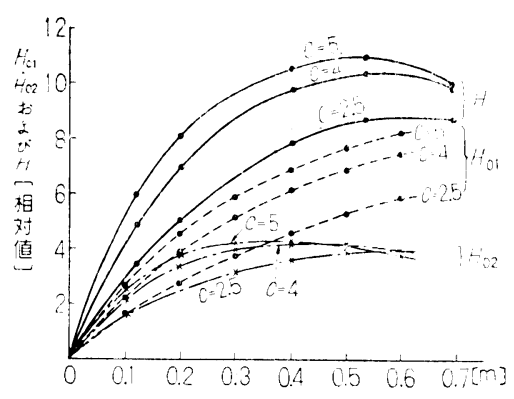

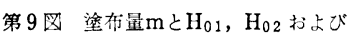
$\mathrm{H}$ との関係

き $\gamma \doteqdot \alpha$ となるととより，一応第 10 図のごとき紫外線 扣よび可視光線に対する透過曲線より求めると, この けい光体については $c \doteqdot 2.3$ を得た。第9図の計算は 一応 $c=2,4,5$ に対して行なっている. 第 9 図より わかるごとく， $H_{01}$ なる紫外線の入射する内面の光東 発散度は塗布厚さとともに増加し, 飽和の傾向がある ひ反し， $H_{02}$ なる外面の光束発散度はある厚さで最大值

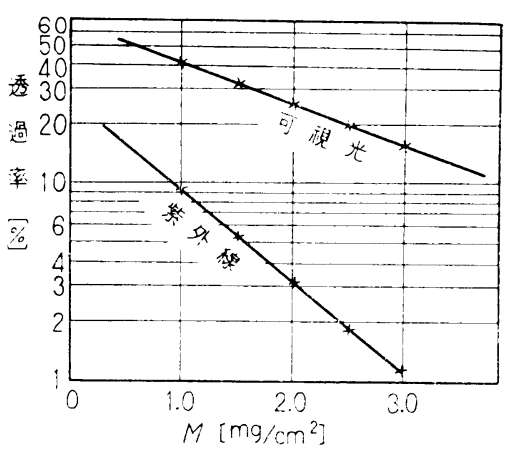

第10图 可祝光わよび柴外線に対する けい光膜の透過率
を有する曲 線灰示す。 この $H_{01}$ 抢 上び $H_{02}$ を 用いて放電 管とした場 合の光束発 散度のHを 求めるため (6.8) 式よ り $\tau_{e 1}, \quad \tau_{e 2}$ を求めな⿰

ればならない・ $\tau_{e 1}, \tau_{e 2}$ を求めるためにガラスの反射率 を0.08, 透過率学 0.9 として計算したのが第 7 図の $\tau_{e 1}$, $\tau_{\epsilon 2}$ の曲線である。したがって全光束発散度 $H$ は第 9 図 曲線に示されるようにある厚さに扔いて最大值を示す曲 線をえがく。との曲線からわかるごとく, 最大光束発散 度を示す最適厚さは $H_{02}$ の最大值を示す最適厚さとはそ の值異にする. かような放電管とした場合の最大光束 発散度を得る最適厚さは(6.8) 式より求的れるが,一。 般的には非常に複雑になるので，ここでは求めなかっ た. 最大光束発散度と各塗布厚さに牥ける光束発散度と の比を求めて，実験結果との比較を第11図に示す、図に 批いてわかるごとく，cの值により明線は相当变化す る.すなわ ちcの值に より最適厚 さは変化す るととがわ かる.との

第11図より, $c$ の值は約 3で, 大体 前述のごと く決定した

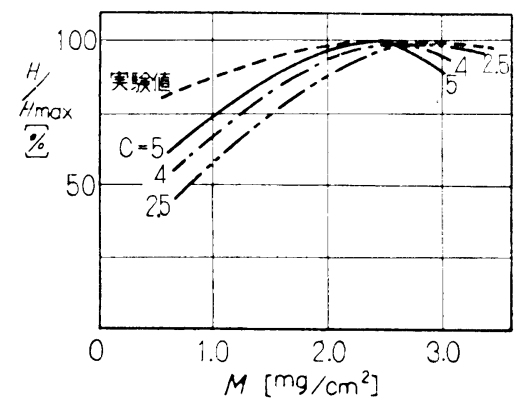

第11圆染布但と光束発散变比

值に等しいととがわかる。

前述のごとくけい光体の粉砕時間により反射率扔よこか 透過率は変化するが，rの值はあまり変化しないことが 実験よりわかった，撖密には粉砕時間こともに 増加する傾向にある。一方柴外線に対する透過寗は第12 図に示すごとく粉砕時間により相当変化することが考え られる。このことよりけい光体の粒度分布がのcの值に 影響を与えるととがわかる。しかも第12図より粉碎時間 が少ないほど $c$ は大になることが考えられ，cが大にな れば第 9 図よりわかるごとくその最大光束発散度の值は 僅加増加し, しかもそのときの最適厚さむ減少してくる ことがいえる。 


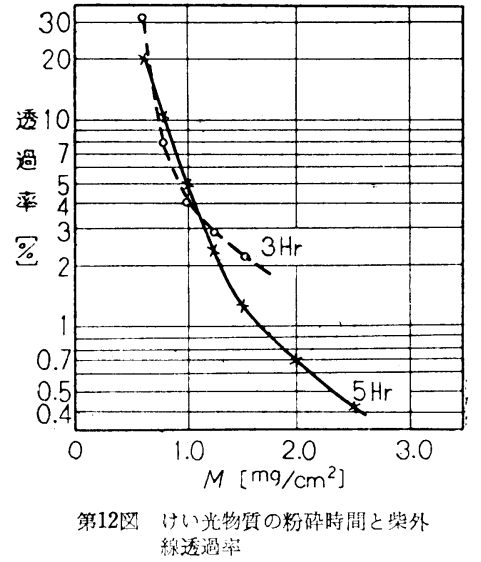

以上述べたで とくけい光放電 管の光束発散度 にはけい光体の 可視光線の透過 率, 反射率も重 要であるけれど も, 紫外線に対 する吸収係数の 様子もその光束 発散度を最高に するには重要な 因子をなしてい

る.しかし，その紫外線に対する罗收係数だけではなく その反射率专㻎要視しなければならなと考光られる。 それは紫外線に対守る反射がよい場合，紫外線 energy の発光への利用度が減劣るからである。本報告ではての 点につき詳しく娭討していないが，次の機会に述べるこ とにする。

な抢，また汸い光体の䊀度の問題も，粒度が大きくな り，しかも薄い厚さのときは沙い光膜が均質とみなされ にくくなり，上述の理諭的取扱いからもずれるととは明 らかである。乙の場合は上述の膜内に招ける相互反射等 は考慮できず, 忠たけい光膜の薄いととろではけい光体 がまばらに散って，素通りの部分があり，粒子が一層に 並んでいるととが想像される。したがって厚さと光束発 散度との関係はこの場合簡単には行かず，場所場所の精 子の大きさ等平均粒度にも関係し複雑になる。上述の実 験結果の第11図を見ても，塗布量が $1 \mathrm{mg}$ 以下の場合は かかる原因で実験值と一致していない上うに考えられ る.しかしとの $1 \mathrm{mg}$ という值はけい光体の粉砕時間, すなわち粘度によって異なるため，一概には塗布量の臨 界值はいえない，实験例では，どうも最大值索出最適 厚さより萝い場合はすでにかかる傾向になるのではなか ろうかと考光られ，本理諭式と実駚值と老比較検討する 場合には，加无見地加もっと䊉度の細加い，すなわ ち䊀硦時間の長いけい光体について検討しなければなら ないと考えられる。

\section{結 言}

けい光膜の紫外線の励起による発光につき, 彷来考虑 されていなかった内部に扮ける散乱を考虑して，以い光 薄膜の光学的特性と発光の光束発散度との関伯式在求め た，その場合けい光膜の紫外線の入射方側（内面）と そうでない侧 (外面) の光束発散度 $H_{01}$ 就よび $H_{02}$ に わけ，それそれれの強度と膜の厚さとの関係を（3.6）打 よび（3.2）式のごとく明らかにした。
次にけい光放電管のごとき円筒内面に鉒布した場合, 円筒内面に招ける相互反射を考慮して内面の光束発散度 を論じ，その結果，円筒の長さと直径の比，すなわち $k_{r}$ により内面光束発散度は変化するととを明らかにすると ともに，円筒の中央部の光束発散度が $k_{r}>7$ 亿扔いて最 大值に達するが，内面のけい光膜の反射率によりその值 も少し変ることが判明した。

また, 外面光束発散度に対し，加加円筒内面に括け る相互反射を考光，さらに管壁ガラスの反射率扔よび透 過率を考虑した澉密な一般式を(6.8) 式のごとく咅き出 した，その結果より内面の光束発散度も外面に対し，ほ とんぞそのまま寄与していることが（6.8），(6.9）式よ り判明した。な赪, 外面抢よび内面の光束発散度に対し て紫外線のい光膜に対する吸收係数や反射率等が非常 に重要な因子をなしていることが判明した。すなわち，

(3.2), (3.9) 式比打る $c=\alpha^{\prime} / \gamma$ の值で, このcの值 が大きいと光本発散度は增加する. 実除にはけい光体の 粒度により変化するが $2 〜 8$ 程度のものである。

以上の結果より紫外線励起による汁い炎膜の発光と塗 布状態の理論的関係が導き出されたとともに, けい光灯 のごとき場合の最高光束発散度咅得るための解析が容易 にできるようになり，それらが実際の数值例ともよく一 致していることが判明した。な招，本論文の結果は他の しげきの励起によるけい光膜の発光に対しても適用でき る.

終りに, 本研究に関し種々ご便宜をはかっていただい た三.菱電機研究所の山下博典, 竹田俊幸, 並びに実験に 協力していただいた助手市瀬正行氏に感謝いたします.

(受付 $35-3-28$ )

\section{参考 文 献}

1) R.N. Thayer : Electrocham. 87 (1945)

2）伴野正美，11口千夫：生産と電気 3 (昭.26) 9

3) Glocker, Kaupp and Widman : Ann.der. Phys. 85 (1928) 313

4) P. Kubelka : J.O.S.A. 38 (1948) 448

5) P.Mcon: J.O.S.A 31 (1941) 223

6) Channon. Renwich and Storr: Proc. Roy. Soc.

94 (1918) 222

P. Kubelka: J.O.S.A 44 (1954) 330

7) 坊 搏, 竹山説三：照学誌41 (楒32) 312

\section{付録 I けい光膜内の発光}

第 2 図のごとき厚さdなるけい光膜のある位置に扔い

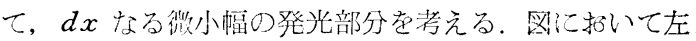
右へ強さなる光が出るものとすれば，光はけい光膜内で 反射をくり返光しながら表面出てくる。したがって膜 内で相互反射理䜽を適用して求めねね゙ならない。 
一般に相互反射の基礎式は次のようにか沙る7 .

$$
H_{i}=H_{0 i}+\sum_{i \neq i}^{n} b_{j i} \cdot H_{j}
$$

ここで $H_{0 i}, \mathrm{H}_{0 i}$ は相互反射系をなす $i$ 面, $\mathrm{j}$ 面の初わの 平均光束発散度, $H_{i}, H_{i}$ は相互反射後の平均光束発散 度, $b_{j i}$ はその $i$ 面と $\mathrm{j}$ 面の幾何学的配犆とその面の反射 率により定まる常数である.

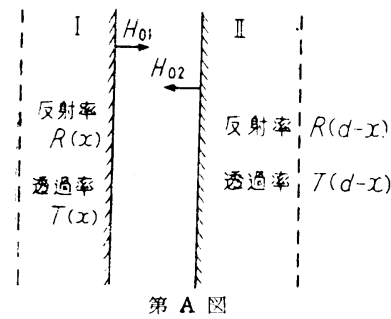

この(1)式を第 2 図に 適用する場合, 第 2 図 老等伍的に第A図のよ うに反射率扰上び透過 率がそれだれ $R_{(x)}, R$ (a-x) 扰よびT(x), T(a $-x)$ なる I, IIの面とし

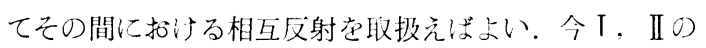
初期光束発散度を $H_{01}, H_{02}$ とすれば，

$$
\begin{aligned}
& H_{1}=H_{01}+b_{21} \cdot H_{2} \\
& H_{2}=H_{02}+b_{12} \cdot H_{1}
\end{aligned}
$$

となり， $b_{21}=R_{(x)}, b_{12}=R_{(d-x)}$ である。 したがって(2)式 より $H_{01}=H_{02}$ として

$$
\begin{aligned}
H_{2} & =\frac{1-b_{12}}{1-b_{12} \cdot b_{21}} \cdot H_{01} \\
& =\frac{1+R_{(d-x)}}{1-R_{(d-x)} \cdot R_{(x)}} \cdot H_{01} \\
H_{1} & =\frac{1+R_{(x)}}{1-R_{(x)} \cdot R_{(d-x)}} H_{01}
\end{aligned}
$$

となる。したがって第 2 図の $x$ 点の位置より $x=d$ なる 面に出てくる光は

$$
\begin{aligned}
H_{d} & =H_{1} \cdot T_{(d-x)} \\
& =\frac{1+R_{(x)}}{1-R_{(x)} \cdot R_{(d-x)}} \cdot T_{(d-x)} \cdot H_{01}
\end{aligned}
$$

となる、愿さbなる打光膜に扔いては(4)式さ箖分して

$$
H=\int_{0}^{d} \frac{1-R_{(x)}}{1-R_{(x)} \cdot R_{(d-x)}} T_{(d-x)} \cdot d H_{01}
$$

となる，本綸文の場命， $d H_{01}=\alpha^{\prime} k_{0} u_{0}-\alpha^{\prime}{ }_{x} d^{\prime} x$ である.

\section{付録 III ガラス壁の影響}

線 6 図に找いて， $H_{01}, H_{02}$ をガラスを付师ない場合の 各面の光束発散度とし, 相互反射後各面 I, II, III, IV に扔ける光束発散度を $H_{1 g}, H_{2}, H_{3}, H_{4 g}$ とすれば， 相互反射の方程式は

$$
\begin{aligned}
& H_{1 g}=H_{01}+H_{3} \cdot T(d) \\
& H_{2}=H_{02}+H_{3} \cdot b_{32} \\
& H_{3}=H_{2} \cdot b_{23} \\
& H_{4 g}=\tau_{g} \cdot H_{2}
\end{aligned}
$$

ただし， $R_{(d)}, T_{(d)}$ はけい光体の厚さdなるものの反 射率，透過率で，ガラスのそれを $\rho_{g}, \tau_{g}$ とする。

$$
\text { 屯た } b_{23}=\rho_{g}, b_{32}=R_{(d)} \text { となる。 }
$$

すると

$$
H_{3}=\frac{b_{23}}{1-b_{23} \cdot b_{32}} \cdot H_{02}=\frac{\rho_{g}}{1-\rho_{g} \cdot R_{(d)}} \cdot H_{02}
$$

$$
\begin{aligned}
& H_{1 g}=H_{01}+T_{(d)} \cdot H_{3}=H_{01} \\
& +\frac{\rho_{q} \cdot T_{(d)}}{1-\rho_{g} \cdot R_{(d)}} H_{02}
\end{aligned}
$$

よって，またガラス在透過して出てくる光 $H_{4 g}$ は

$$
\begin{aligned}
& H_{40}=\tau_{g} \cdot H_{2}=\tau_{g}\left(H_{02}+H_{3} \cdot b_{32}\right) \\
& =\tau_{g}\left(1+\frac{R_{(d)} \cdot \rho_{g}}{1-\rho_{g} \cdot R_{(d)}}\right) H_{62} \\
& =\frac{\tau_{g}}{1-\rho_{g} \cdot R_{(d)}} H_{02}
\end{aligned}
$$

したがってこの場合はガラスの透過率が 過率 $\tau_{e}$

$$
\tau_{e}=\frac{\tau_{g}}{1-\rho_{g} \cdot R_{(d)}}
$$

になったと考えて取扱えばよいととがわかる。 